\title{
The Impact of Financial Literacy on New Venture Survival
}

\author{
Sean Wise ${ }^{1}$ \\ ${ }^{1}$ Department of Entrepreneurship \& Strategy, Ted Rogers School of Management, Ryerson, Toronto, Canada \\ Correspondence: Sean Wise, Department of Entrepreneurship \& Strategy, Ted Rogers School of Management, \\ Ryerson University, Toronto, M5B 2K3 Canada. Tel: 1-416-979-5000 ext. 2254. E-mail: sean.wise@ryerson.ca
}

Received: September 30, 2013

doi:10.5539/ijbm.v8n23p30

\author{
Accepted: October 28, 2013 Online Published: November 15, 2013 \\ URL: http://dx.doi.org/10.5539/ijbm.v8n23p30
}

\begin{abstract}
This is an investigation into the impact of financial literacy on new venture survival. A model is proposed in which increased adoption of financial tools (e.g. financial statements and financial ratios) leads to increased frequency of financial statement generation which in turn increases the likelihood of loan repayment and decreases the probability of venture failure. A structural model was then tested using data from 509 young entrepreneurs in Canada who had received start up loans through their participation in a program by the Canadian Youth Business Foundation. This research found that increases in financial literacy led to more frequent production of financial statements. This research found that entrepreneurs who produced financial statements more frequently had a higher probability of loan repayment and a lower probability to close their venture involuntarily.
\end{abstract}

Keywords: financial literacy, loan default, microcredit, new venture creation

\section{Introduction}

New venture creation is vital to a healthy economy. Entrepreneurship is a force for driving job creation, innovation, economic growth, and fueling healthy and sustainable communities (STARTUP, Canada). New venture founders contribute to economic growth through a diverse range of behaviours, including innovation, resource combination, and increased competitive pressures (Wong, Ho, \& Autio, 2005). Entrepreneurship is vital on many levels, as evidenced by public policy schemes that encourage new venture creation and development (De Carolis, Litzky, \& Eddleston, 2009). Further, when it comes to youth, entrepreneurship represents an increasingly important source of employment (Owualah, 1999; Williams, 2004). For young people, starting a new venture can be very difficult. The financial, social, and knowledge capital stocks of young entrepreneurs are often deficient, and these founders often lack the creditability necessary to obtain these resources externally (Khaire, 2010; Zott \& Huy, 2007). Scholars have long noted that young firms have higher failure rates than established firms (Baum, Calabrese, \& Silverman, 2000, p. 267). Notwithstanding the importance of new ventures, the 5-year survival rate of new ventures is less than $50 \%$ on average (Fritsch \& Weyh, 2006), and ten years after starting up only $10 \%$ of the ventures remain in the market (Timmons \& Spinelli, 2004). In Canada specifically, a new firm has a $77 \%$ chance of surviving its first year and about only a $36 \%$ chance of surviving the first five years (Baldwin \&Statistics Canada Analytical Studies Branch, 2000).

There are a lot of theories as to why so many new ventures fail. One such theory revolves around financial literacy. Inadequate business acumen, including poor financial literacy undermines entrepreneurial activity (Bosma \& Harding, 2006). Financial management is listed as one of the critical managerial competencies in new venture creation and development (Timmons \& Spinelli, 2007:269). Most scholars agree that entrepreneurs, regardless of their age, are routinely involved in decision-making activities concerning resource acquisition, allocation and utilisation. Such activities almost always have financial consequences and thus, in order to be effective, entrepreneurs must be financially literate (Oseifuah, 2010). Individuals and micro-entrepreneurs often lack sufficient financial literacy to make the complex financial decisions they face (Drexler, Fischer, \& Schoar, 2010). This is unfortunate, since according to Oseifuah (2010) 'Financial literacy among youth entrepreneurs . . . contributes meaningfully to their entrepreneurship skills.' Entrepreneurs wanting to start new ventures need to feel confident with their personal finances, as well as the finances of the new venture (Kotzè \& Smit, 2008). If individuals are illiterate concerning their personal finances, their financial management of new ventures will also be lacking and will lead to reduced new venture creation and possible failures of SMEs (Kotzè \& Smit, 2008). What these perspectives all seem to agree on is that nascent entrepreneurs suffer from a lack of financial literacy and such deficiency undermines the probability of their new venture success. 
In recent years, financial literacy has gained the attention of a wide range of major banking companies, government agencies, grassroots consumer and community interest groups, and other organizations (Braunstein \& Welch, 2002).

The literature on SME loan default is sparse when compared to the literature on corporate default (McCann \& McIndoe-Calder, 2012). There are many contributing factors why a founder might default on their startup seed loan. These may include but are not limited to: lack of business success; perception of unrealistic terms; poor financial acumen; weak management, etc. Bichanga \& Aseyo (2013, p. 323) found that borrower training is important in that it empowers borrowers with knowledge on utilization of loan funds, which in turn would translate to lower default rates. According to Shepherd, Douglas, \& Shanley (2000), the risks of new venture failure are resultant from numerous sources, including but not limited to: the costs of learning new tasks (Stinchcombe, 1965; Singh, Tucker \& House, 1986); new product characteristics (Aldrich \& Auster, 1986); the strength of conflicts regarding new organizational roles (Stinchcombe, 1965; Singh et al. 1986); the presence or absence of informal organizational structures (Stinchcombe, 1965); the stability of key stakeholder links (Stinchcombe, 1965; Singh et al., 1986); and the degree of organizational stability/inertia (Hannan \& Freeman, 1984).

The lack of knowledge of financial management contributes to the low prevalence of new venture creation, and ultimately the high failure rate of Small and Medium-sized Enterprises (SMEs), as most entrepreneurs are intimidated by financial management (Timmons \& Spinelli, 2007, p. 388). Most scholars agree that entrepreneurs, regardless of their age, are routinely involved in decision-making activities concerning resource acquisition, allocation and utilisation. Such activities almost always have financial consequences and thus, in order to be effective, entrepreneurs must be financially literate (Oseifuah, 2010). Recent papers argue that "managerial capital" or business skills (including financial literacy) are an important driver of firm growth and a key determinant of productivity (e.g., Bloom, Mahajan, McKenzie \& Roberts, 2010; Bruhn, Karlan \& Schoar, 2010). Financial literacy among youth entrepreneurs contributes meaningfully to their entrepreneurship skills (Oseifuah, 2010).

Definitions suggest that financial literacy includes increases in financial knowledge or skills and changes in financial behaviour (Hilgert, Hogarth, \& Beverly, 2003; Mandell, 2004). Noctor, Stoney, \& Stradling (1992) defined financial literacy as: "the ability to make informed judgements and decisions regarding the use and management of money". Anthes (2004, p. 49) concludes that financial literacy is:

The ability to read, analyse, manage and communicate about personal financial conditions that affect material well-being.....the ability to discern financial choices, discuss money and financial issues without (or despite) discomfort, plan for the future.

An increase in financial literacy, resulting from financial education, should lead to more informed and effective financial decisions (Altman, 2012). According to (Kotzè \& Smit, 2008) the consequences of financial illiteracy include: spending more than their income; the lack of, or insufficient, record keeping; not planning and implementing a regular investment programme; and making incorrect financial decisions. Conversely, entrepreneurs with higher ex ante financial literacy further exhibited some improvements in business performance and sales. (Bruhn \& Zia, 2011). According to Oseifuah (2010), the following are some of the key elements of financial literacy skills and knowledge often cited in the literature:

- Mathematical literacy and standard literacy such as basic numeracy and comprehension skills.

- Financial understanding about the nature and forms of money, how it is used, and the consequences of consumer decisions.

- Financial competence, such as the understanding of the main features of basic financial services, attitudes to spending money and saving, understanding financial records and appreciating the importance of reading and maintaining them, an awareness of the risks associated with financial products, and an appreciation of the relationship between risk and return.

- Financial responsibility - the ability to make appropriate personal life choices about financial issues, understanding consumer rights and responsibilities, the ability, and confidence to seek assistance when things go wrong.

In the Oseifuah (2010) study, the theoretical framework for measuring financial literacy was adapted from a model originally developed by the Media Research Consultants Pte Ltd (2005). The Research Consultants Pte Ltd model is based on the definition of financial literacy: 'the ability of an individual to make informed judgements and take effective decisions in managing their finances'. The framework has two dimensions of financial literacy: 
actions and knowledge. Knowledge focuses on a person's understanding of common financial terms and products/services. Action involves the use of the financial knowledge in the following areas: budgeting, investment, financial planning, keeping of accurate financial records and the type of bank accounts kept, among others.

Unfortunately, the literature on financial literacy indicates that there is no standardised measure of financial literacy (Moore, 2003; Cole \& Fernando, 2008). The evidence on the effects of business training on entrepreneurial outcomes is also scarce; research is needed on the financial education of entrepreneurs and the outcomes resulting from this education on new venture finances (Kotzè \& Smit, 2008; Karlan \& Valdivia, 2010) Similarly, Oseifuah (2010) stated that more research is needed to verify in specific and practical terms the level and impact of financial literacy on youth entrepreneurs. Based on these research calls, it is the aim of this research to contribute to the dialogue on the impact of financial literacy on new venture survivorship.

Further, while some evidence has been presented correlating lower mortgage defaults to higher levels of financial literacy (Lusardi \& Mitchell, 2008; Agarwal, Amromin, Ben-David, Chomsisengphet \& Evanoff, 2010), similar work exploring loan default rates and entrepreneurial financial literacy remains inconclusive. Karlan \& Valdivia (2010) did not find that increases in financial literacy impacted business outcomes. However, Drexler et al. (2010) did find that increases in financial literacy did impact business outcomes. Similarly, Bruhn \& Zia (2011) found entrepreneurs with higher ex ante financial literacy did show some improvements in business performance and sales. This research attempts to address this deficiency by exploring the following hypotheses:

RQ1: Does an increase in financial literacy of young entrepreneurs increase the probability of loan repayment amongst new ventures?

RQ2: Does an increase in financial literacy will decrease the probability for involuntary new venture closure?

This research study investigates the quantitative relationship between financial literacy, loan repayment and new venture failure. This research proposes the following model, an increase in an entrepreneur's familiarity with financial statements financial and ratios leads to an increase in financial literacy. An increase in financial literacy leads to less loan default and less involuntary business closure. Defaulting on a loan is impacts the chance that the entrepreneur will have to close the business.

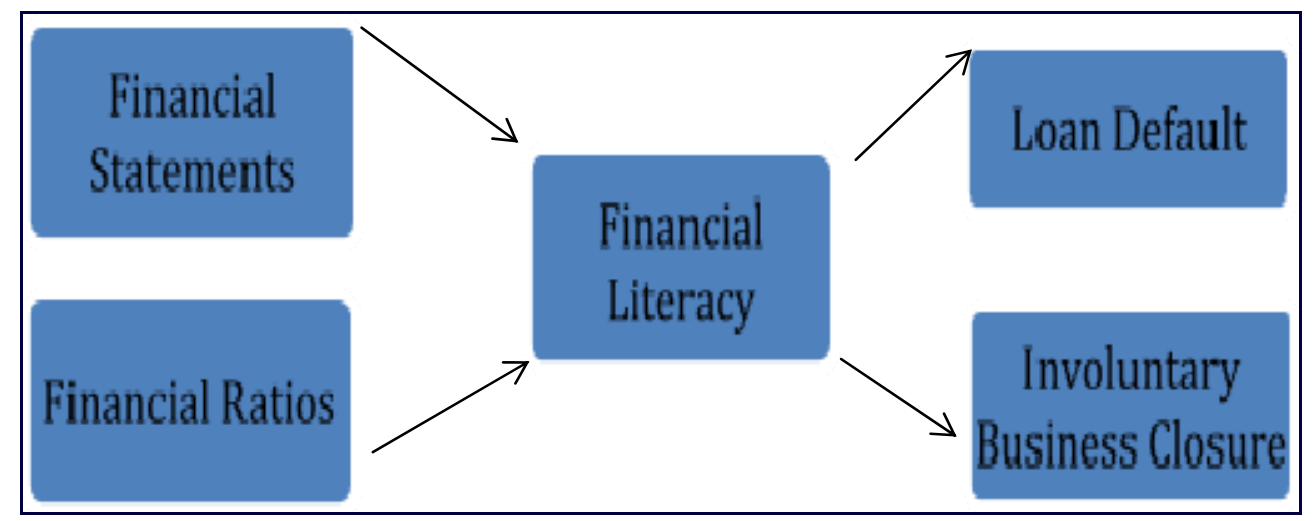

Figure 1. Proposed financial literacy model

\section{Method}

\subsection{Participant (Subject) Characteristics}

This research study investigated the quantitative relationship between financial literacy and two economic results (i.e. loan default and involuntary business closure) amongst nascent entrepreneurs. This study surveyed a range of young entrepreneurs participating in a formalized institutional microcredit program operated by the Canadian Youth Business Foundation (CYBF). CYBF is a Canadian non-profit organization dedicated to "driving Canada's business success by helping youth help themselves" (CYBF, 2006: ii).

\subsection{Sampling Procedures}

The data used in this study represent responses from 509 young entrepreneurs surveyed in the autumn of 2012. Data was provided by CYBF, which asked 1400 current CYBF clients about their experience the microcredit 
program. The survey was conducted in both English and French, at the option of the respondent. The response rate of $38.6 \%$ is typical for these surveys.

Table 1. Demographic information about sample

\begin{tabular}{cccccc}
\hline & N & Minimum & Maximum & Mean & Std. Deviation \\
\hline REVENUE & 480 & 0 & $\$ 18001000$ & $\$ 262723.89$ & $\$ 1315937.495$ \\
AGE & 509 & $18-21$ & $35-39$ & 27 & .907 \\
Level of Education & 509 & No High School Graduate Degree University Degree & .913 \\
NEWINC & 509 & 0 & $+\$ 132406$ & $+\$ 40000$ & 1.798 \\
Valid N (listwise) & 480 & & & & \\
\hline
\end{tabular}

Table 1 provides some summary demographic information about the entrepreneurs and their firms, where: REVENUE represents the revenue of the new venture; AGE represents the age of the entrepreneur at the start of the program; Level of Education represents the highest level of schooling of the entrepreneur; NEWINC represents the change in the entrepreneur's level of personal income over the program duration.

\subsection{Measures and Covariates}

Our survey data included questions that explored the entrepreneur's knowledge, use and frequency of financial statements (e.g. cash flow statement, balance sheet) and financial ratios (e.g. P/E ratio) as well as collected data on loan repayment and new venture status (e.g. closed, ongoing). For the most part these questions focused on changes on usage over the period of CYBF program affiliation. The independent variables, which we tested to see their impact on loan repayment and business failure were: change in usage of financial statements (DSF); and change in usage of financial ratios (DRAT). DSF and DRAT lead to a change in the frequency of financial statements generation (DFSF). The dependant variable was envisioned to be both "loan repayment" (GLOAN, i.e., was the CYBF loan repaid) and "business failure" (INVOL, i.e., was the business forced to shut down).Initially we anticipated any increase in DSFS, DRAT and DFS to have a positive impact on loan repayment and a negative impact on business failure, e.g., as one uses financial statements and ratios more frequently one is able to better monitor the financial health of the new venture and by doing so more easily avoid involuntary venture closure.

Table 2. Variable operationalization

\begin{tabular}{lll}
\hline Variable & Definition & Type \\
\hline DSF & change in usage of financial statements & IV \\
DRAT & change in usage of financial ratios & IV \\
DFSF & change in the frequency of financial statements generation & IV, DV \\
GLOAN & CYBF loan repaid & DV \\
INVOL & business forced to shut down & DV \\
\hline
\end{tabular}

Table 2 lists the specific survey variables there were included in the study.

\subsection{Research Design}

This study surveyed young entrepreneurs from across Canada about their financial literacy so as to determine what impact such knowledge has on new venture failure. The data used in this study represents responses from 509 young entrepreneurs surveyed in the autumn of 2012. Data was obtained from biannual survey undertaken by CYBF. In total CYBF solicited 1400 current CYBF clients (i.e. those in receipt of CYBF startup loans). The 
survey was conducted in both English and French, at the option of the respondent. The response rate of $38.6 \%$ is typical for these surveys. Table 2 provides some summary demographic information about the respondents and their firms.

Following Hair, Anderson, Tatham, \& Black (1998), structural equation modelling (SEM) was undertaken. Structural equation modelling is a statistical technique for testing and estimating causal relations using a combination of statistical data and qualitative causal assumptions. SEM typically involves four interrelated steps (Hooper, Coughlan, \& Mullen, 2008): (1) model specification, where one specs a model; (2) model estimation, where one confirmsthe fit between model and data is sufficient to rely upon such (measured through the Confirmatory Fit Index, i.e. CFI); (3) model evaluation, in which one examines the p-values to ensure estimates of parameters are reliable; and (4) model modification, in which one examines the estimates themselves (sign, relative magnitude) to see which factors have greater impact on the DV and if necessary the model is modified to increase fit.SEM is a popular method of analysis that allows for examining various models which could explain data structures (Moutinho\& Hutcheson, 2011, p. 299). One of the strengths of SEM is that it can examine multiple relationships within a model simultaneously (Hair et al., 1998).

This research followed the steps laid out by Hooper, Coughlan, \& Mullen (2008), and first spec'd a model based on Figure 1. Several model variants were tested to confirm a strong fit between model and data. Most generated an CFI below the acceptable threshold set out in Hooper, Coughlan, \& Mullen (2008), i.e. CFI $\geq 0.95$. One model, illustrated as Figure 2, was found to have the strongest fit between model and data $(\mathrm{CFI}=0.955)$. The researcher then examined the various p-values associated with that model and confirmed they were reliable. Finally the researcher reviewed the sign and relative magnitude to better understand which variables have the greater impact on Loan Repayment and Business Closure. No further modifications to the model were required.

\section{Results}

Table 3. Descriptive statistics

\begin{tabular}{cccccc}
\hline & N & Minimum & Maximum & Mean & Std. Deviation \\
\hline DFSF & 509 & -1 & 1 & .25 & .545 \\
DRAT & 509 & -1 & 1 & .10 & .333 \\
DFS & 509 & -3 & 3 & .63 & 1.142 \\
GLOAN & 509 & 0 & 1 & .97 & .169 \\
INVOL & 509 & 0 & 1 & .04 & .185 \\
Valid (listwise) & 509 & & & & \\
\hline
\end{tabular}

A table of descriptive statistics is presented in Table 3; it shows the minimum, maximum, mean and standard deviation of the key operationalized variables. A chart of correlations is presented as Table 4. 
Table 4. Correlations amongst key variables

\begin{tabular}{|c|c|c|c|c|c|c|}
\hline & & GLOAN & INVOL & DFS & DFSF & DRAT \\
\hline \multirow[t]{3}{*}{ GLOAN } & Pearson Correlation & 1 & $-.344 * *$ & -.035 & $.122 * *$ & .050 \\
\hline & Sig. (2-tailed) & & .000 & .425 & .006 & .256 \\
\hline & $\mathrm{N}$ & 509 & 509 & 509 & 509 & 509 \\
\hline \multirow[t]{3}{*}{ INVOL } & Pearson Correlation & $-.344 * *$ & 1 & -.079 & $-.107 *$ & .009 \\
\hline & Sig. (2-tailed) & .000 & & .077 & .016 & .847 \\
\hline & $\mathrm{N}$ & 509 & 509 & 509 & 509 & 509 \\
\hline \multirow[t]{3}{*}{ DFS } & Pearson Correlation & -.035 & -.079 & 1 & $.250^{* *}$ & $.103 *$ \\
\hline & Sig. (2-tailed) & .425 & .077 & & .000 & .020 \\
\hline & $\mathrm{N}$ & 509 & 509 & 509 & 509 & 509 \\
\hline \multirow[t]{3}{*}{ DFSF } & Pearson Correlation & $.122 * *$ & $-.107 *$ & $.250 * *$ & 1 & $.140 * *$ \\
\hline & Sig. (2-tailed) & .006 & .016 & .000 & & .002 \\
\hline & $\mathrm{N}$ & 509 & 509 & 509 & 509 & 509 \\
\hline \multirow[t]{3}{*}{ DRAT } & Pearson Correlation & .050 & .009 & $.103^{*}$ & $.140^{* *}$ & 1 \\
\hline & Sig. (2-tailed) & .256 & .847 & .020 & .002 & \\
\hline & $\mathrm{N}$ & 509 & 509 & 509 & 509 & 509 \\
\hline
\end{tabular}

**. Correlation is significant at the 0.01 level (2-tailed).

*. Correlation is significant at the 0.05 level (2-tailed).

Following standard SEM methods (Hooper, Coughlan, \& Mullen, 2008) generated the model illustrated as Figure 2.

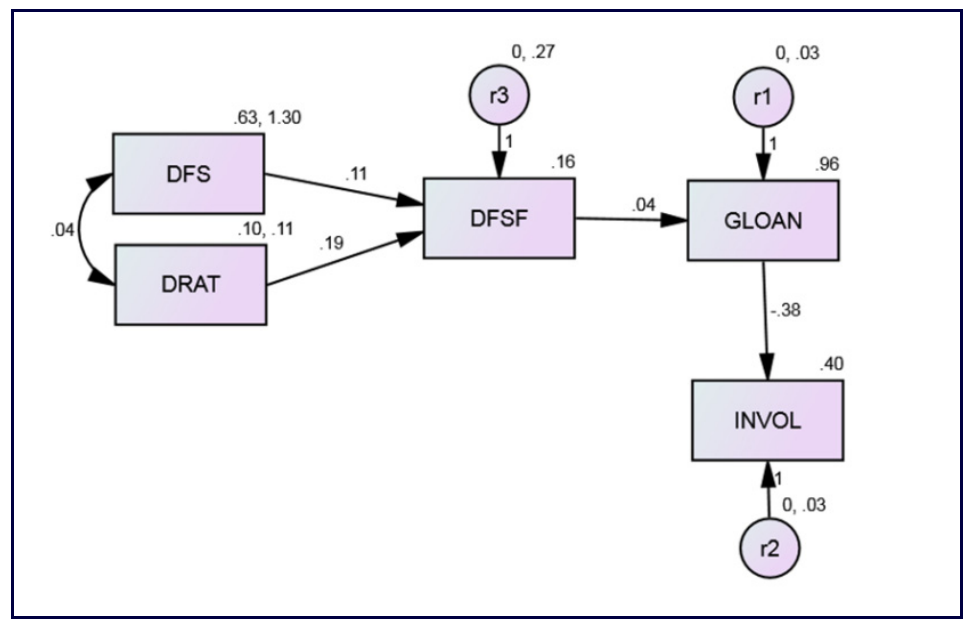

Figure 2. SEQ model with parameter estimates 
In SEM, it is important to examine the "fit" of an estimated model to determine how well it models the data. The output of SEM programs includes matrices of the estimated relationships between variables in the model. Assessment of fit calculates how similar the predicted data are to matrices containing the relationships in the actual data. In this research the CFI is 0.955 , indicating a strong fit between the predicted data and actual data. The $\mathrm{p}$ value for each link in the model is also found to be valid. Parameter estimation (in SEM) is undertaken next by comparing the actual covariance matrices representing the relationships between variables and the estimated covariance matrices of the best fitting model. In this research the estimates of the parameter weights of each link in the model are found valid since the model itself has a good fit $(\mathrm{X} 2 / \mathrm{DF}=2.00$ and a $\mathrm{RMSEA}=0.44)$. It is also worth noting that the link between an increase in financial statement generation (DFSF) and Involuntary business closure (INVOL) was found to be not significant and dropped from the model. This can be interpreted as: by preparing financial statements more frequently, entrepreneurs avoided loan default, and by avoiding loan default keep their new ventures open. It would also indicate that it is the loan default that leads to business failure, not the failure to generate financial statements.

This result shows that an increase in the entrepreneur's knowledge of financial statements (DFS) and financial ratios (DRAT) leads to an increase in the frequency that financial statements are generated (DFSF) and an increase in the frequency that financial statements are generated (DFSF) leads to more loans being paid back (GLOAN, e.g. deemed good loans) which in turn leads to less involuntary venture shutdowns (INVOL).

\section{Discussion}

Oseifuah (2010) called for further research into the level and impact of financial literacy on youth entrepreneurs. This research found that increases in financial literacy led to more frequent production of financial statements. One can hardly produce financial statements without being financially literate; further, a lack of comfort with financial matters (e.g., financial literacy) would correlate to dismissing the use of such. An increase in financial literacy of young entrepreneurs was found to increase the probability of loan repayment amongst new ventures. This is in line with the theoretical underpinnings of this work. One can picture a young entrepreneur requiring more business acumen input than say a serial entrepreneur. Young entrepreneurs by definition are likely to have little experience and low levels of both business acumen and financial literacy. By exposing young entrepreneurs to the value of financial literacy, mentors are arming founders with tools necessary to make intelligent financial decisions.

This research found that entrepreneurs, who produced financial statements more frequently, tended to default on their loans less and had less likelihood to close their venture involuntarily. Perhaps it is because (as Oseifuah (2010) suggests) increased financial literacy leads to better decision making or increased financial responsibility. An increase in financial literacy was found to decrease the probability for involuntary new venture closure.

In producing this research the author hopes to contribute to our understanding of the impact of financial literacy on new venture success, called for by Kotzè \& Smit (2008) and others. Unlike Karlan \& Valdivia (2010), but like Drexler et al. (2010) we found that increases in financial literacy did impact business outcomes. Similar to Bruhn \& Zia (2011), which found that entrepreneurs with higher ex ante financial literacy further exhibited some improvements in business performance and sales, this study found that those who increase their financial literacy and use of financial tools have better new venture success.

From a practitioner's perspective this research highlights not only the importance of financial literacy on new venture creation but the importance of encouraging frequent generation of financial statements by youth entrepreneurs.

Future researchers might continue this dialogue by running a controlled experiment, giving one group of entrepreneur's extensive financial literacy education while another group would receive none and then comparing the impact of new venture failure which results. Similarly, it would be interesting to explore the impact of monthly mandatory product of financial statements on new venture failure.

\section{References}

Agarwal, S., Amromin, G., Ben-David, I., Chomsisengphet, S., \& Evanoff, D. D. (2010). Learning to cope: Voluntary financial education and loan performance during a housing crisis. The American Economic Review, 100(2), 495-500. http://dx.doi.org/10.1257/aer.100.2.495

Aldrich, H., \& Auster, E. R. (1986). Even dwarfs started small: Liabilities of age and size and their strategic implications. Research in Organizational Behavior, 8, 165-198. http://dx.doi.org/10.1016/j.socec.2012.06.002

Altman, M. (2012). Implications of behavioural economics for financial literacy and public policy. The Journal of 
Socio-Economics, 41(5), 677-690.

Anthes, W. (2004). Financial literacy in America: A perfect storm, a perfect opportunity. Journal of Financial Service Professionals, 8(6), 49-56.

Audretsch, D. B., \& Mahmood, T. (1995). New firm survival: new results using a hazard function. The Review of Economics and Statistics, 77(1), 97-103. http://dx.doi.org/10.2307/2109995

Baldwin, J. R., \& Statistics Canada Analytical Studies Branch. (2000). Determinants of innovative activity in Canadian manufacturing firms: the role of intellectual property rights. Analytical Studies Branch, Statistics Canada.

Baum, J. A., Calabrese, T., \& Silverman, B. S. (2000). Don't go it alone: Alliance network composition and startups' performance in Canadian biotechnology. Strategic Management Journal, 21(3), 267-294. http://dx.doi.org/10.1002/(SICI)1097-0266(200003)21:3<267::AID-SMJ89>3.0.CO;2-8

Bay, C., Catasús, B., \& Johed, G. (2012). Situating financial literacy. Critical Perspectives on Accounting. Science Direct. http://dx.doi.org/10.1016/j.cpa.2012.11.011

Bichanga, W. O., \& Aseyo, L. (2013). Causes of Loan Default within Micro Finance Institutions in Kenya. Interdisciplinary Journal of Contemporary Research in Business, 4(12), 316-335.

Bloom, N., Mahajan, A., McKenzie, D., \& Roberts, D. (2010). Why do firms in developing countries have low productivity? American Economic Review, 100(2), 619-23. http://dx.doi.org/10.1257/aer.100.2.619

Bosma, N., \& Harding, R. (2006). Global entrepreneurship monitor 2006 results report. Babson Park, MA: Babson College.

Bosse, D. A. (2009). Bundling governance mechanisms to efficiently organize small firm loans. Journal of Business Venturing, 24(2), 183-195. http://dx.doi.org/10.1016/j.jbusvent.2008.03.001

Braunstein, S., \& Welch, C. (2002). Financial literacy: An overview of practice, research, and policy. Fed. Res. Bull., 88, 445.

Bruhn, M., Karlan, D., \& Schoar, A. (2010). What capital is missing in developing countries? The American Economic Review, 100(2), 629-633. http://dx.doi.org/10.1257/aer.100.2.629

Bruhn, M., \& Zia, B. (2011). Stimulating managerial capital in emerging markets: the impact of business and financial literacy for young entrepreneurs. World Bank Working Paper, 5642.

Chua, C. T., Goh, J., \& Zhang, Z. (2010). Expected volatility, unexpected volatility, and the cross-section of stock returns. Journal of Financial Research, 33(2), 103-123. http://dx.doi.org/10.1111/j.1475-6803.2010.01264.x

Cole, S., \& Fernando, N. (2008). Assessing the importance of financial literacy. ADB Finance for the Poor, 9(2), $1-6$.

De Carolis, D. M., Litzky, B. E., \& Eddleston, K. A. (2009). Why networks enhance the progress of new venture creation: The influence of social capital and cognition. Entrepreneurship Theory and Practice, 33(2), 527-545. http://dx.doi.org/10.1111/j.1540-6520.2009.00302.x

Drexler, A., Fischer, G., \& Schoar, A. (2010). Keeping it simple: Financial literacy and rules of thumb. Centre for Economic Policy ResearchDiscussion Paper 7994.

Duchesneau, D. A., \& Gartner, W. B. (1990). A profile of new venture success and failure in an emerging industry. Journal of Business Venturing, 5(5), 297-312. http://dx.doi.org/10.1016/0883-9026(90)90007-G

Freiling, J., \& Laudien, S. M. (2013). Explaining new venture failure: A competence-based approach. AIMS 2013 Conference.

Fritsch, M., \& Weyh, A. (2006). How large are the direct employment effects of new businesses? An empirical investigation for West Germany. Small Business Economics, 27(2-3), 245-260. http://dx.doi.org/10.1007/s11187-006-0005-z

Hair, J. F. Jr., Anderson, R. E., Tatham, R. L., \& Black, W. C. (1998). Multivariate data analysis (5th ed.). Upper Saddle River, NJ: Prentice-Hall International.

Hannan, M. T., \& Freeman, J. (1984). Structural inertia and organizational change. American Sociological Review, 49(2), 149-164. http://dx.doi.org/10.2307/2095567

Hilgert, M. A., Hogarth, J. M., \& Beverly, S. G. (2003). Household financial management: The connection 
between knowledge and behavior. Fed. Res. Bull., 89, 309.

Hooper, D., Coughlan, J., \& Mullen, M. (2008). Structural equation modelling: guidelines for determining model fit.

Hymer, S. (1976). The international operations of national firms: A study of direct foreign investment (Vol. 14, pp. 139-155). Cambridge, MA: MIT Press.

Karlan, D., \& Valdivia, M. (2010). Teaching entrepreneurship: impact of business training on microfinance clients and institutions. New Haven, CT, USA, and Lima, Peru: Yale University, Economic Growth Center, and GRADE.

Khaire, M. (2010). Young and no money? Never mind: The material impact of social resources on new venture growth. Organization Science, 21(1), 168-185. http://dx.doi.org/10.1287/orsc.1090.0438

Kotzè, L., \& Smit, A. (2008). Personal financial literacy and personal debt management: the potential relationships with new venture creation. South African Journal of Entrepreneurship and Small Business Management, 1(1), 35-50.

Lavoie, D. (1987). The accounting of interpretations and the interpretation of accounts: The communicative function of "the language of business". Accounting, Organizations and Society, 12(6), 579-604. http://dx.doi.org/10.1016/0361-3682(87)90010-9

Llewellyn, S., \& Milne, M. J. (2007). Accounting as codified discourse..Accounting, Auditing \& Accountability Journal, 20(6), 805-824. http://dx.doi.org/10.1108/09513570710830254

Lusardi, A., \& Mitchell, O. S. (2011). Financial literacy and planning: Implications for retirement wellbeing (No. 17078). National Bureau of Economic Research.

Mandell, L. (2004). Financial literacy, financial failure and the failure of financial education. Buffalo, NY: Department of Finance and Managerial Economics, University at Buffalo.

Mata, F. J., Fuerst, W. L., \& Barney, J. B. (1995). Information technology and sustained competitive advantage: A resource-based analysis. MIS Quarterly, 19(4), 487-505. http://dx.doi.org/10.2307/249630

Media Research Consultants Pte Ltd. (2005). Quantitative research on financial literacy levels in Singapore. report prepared for The MoneySENSE Financial Education Steering Committee (FESC), Singapore.

McCann, F., \& McIndoe-Calder, T. (2012). Determinants of SME Loan Default: The Importance of Borrower-Level Heterogeneity (No. 06/RT/12). Central Bank of Ireland.

Moore, D. (2003). Survey of Financial Literacy in Washington State: Knowledge, Behavior, Attitudes, and Experiences. Technical report 03-39, Social and Economic Sciences Research Center, Washington State University.

Moutinho, L., \& Hutcheson, G. D. (2011). The SAGE dictionary of quantitative management research. Sage.

Noctor, M., Stoney, S., \& Stradling, S. (1992). Financial literacy: a discussion of concepts and competences of financial literacy and opportunities for its introduction into young people's learning. National Foundation for Educational Research.

Oseifuah, E. K. (2010). Financial literacy and youth entrepreneurship in South Africa. African Journal of Economic and Management Studies, 1(2), 164-182. http://dx.doi.org/10.1108/20400701011073473

Owualah, S. L. (1999). Tackling youth unemployment through entrepreneurship. International Small Business Journal, 17(3), 49-59. http://dx.doi.org/10.1177/0266242699173003

Remund, D. L. (2010). Financial literacy explicated: The case for a clearer definition in an increasingly complex economy. Journal of Consumer Affairs, 44(2), 276-295. http://dx.doi.org/10.1111/j.1745-6606.2010.01169.x

Shepherd, D. A., Douglas, E. J., \& Shanley, M. (2000). New venture survival: Ignorance, external shocks, and risk reduction strategies. Journal of Business Venturing, 15(5), 393-410. http://dx.doi.org/10.1016/S0883-9026(98)00032-9

Singh, J. V., Tucker, D. J., \& House, R. J. (1986). Organizational legitimacy and the liability of newness, Administrative Science Quarterly, 31(2), 171-193. http://dx.doi.org/10.2307/2392787

Stinchcombe, A. L. (1965). Social structure and organizations. In J. G. March (Ed.), Handbook of organizations (pp. 142-193). Chicago: Rand McNally. 
Timmons, J., \& Spinelli, S. (2004). New venture strategies: Entrepreneurship for the 21st century. Burr Ridge, IL: Irwin-McGraw-Hill.

Venkatraman, N. (1990). Performance implications of strategic coalignment: a methodological perspective. Journal of Management Studies, 27(1), 19-41. http://dx.doi.org/10.1111/j.1467-6486.1990.tb00751.x

Williams, D. R. (2004). Youth self-employment: Its nature and consequences. Small Business Economics, 23(4), 323-336. http://dx.doi.org/10.1023/B:SBEJ.0000032035.30738.01

Wong, P. K., Ho, Y. P., \& Autio, E. (2005). Entrepreneurship, innovation and economic growth: Evidence from GEM data. Small Business Economics, 24(3), 335-350. http://dx.doi.org/10.1007/s11187-005-2000-1

Zacharakis, A. L., Meyer, G. D., \& De Castro, J. (1999). Differing perceptions of new venture failure: a matched exploratory study of venture capitalists and entrepreneurs. Journal of Small Business Management, 37, 1-14.

Zaheer, S. (1995). Overcoming the liability of foreignness. Academy of Management Journal, 38(2), 341-363. http://dx.doi.org/10.2307/256683

Zott, C., \& Huy, Q. N. (2007). How entrepreneurs use symbolic management to acquire resources. Administrative Science Quarterly, 52(1), 70-105. http://dx.doi.org/10.2189/asqu.52.1.70

\section{Copyrights}

Copyright for this article is retained by the author(s), with first publication rights granted to the journal.

This is an open-access article distributed under the terms and conditions of the Creative Commons Attribution license (http://creativecommons.org/licenses/by/3.0/). 